\title{
VOCABULARY AND LEXICOGRAMMATICAL
} AS READING MAIN PROBLEM AT TARBIYAH'S CLASS IN STAIN MANADO

\author{
Nur Halimah
}

\begin{abstract}
Abstrak
Tulisan ini menelusuri masalah sejumlah mahasiswa Tarbiyah STAIN Manado dalam membaca buku teks, terutama pada tataran kalimat. Hasil pengamatan menunjukkan bahwa masalah utama mahasiswa Tarbiyah adalah keterbatasan penguasaan kosa kata. Kendala ini mengakibatkan membaca menjadi sangat sulit dan hasilnya pun tidak tepat. Mereka tampak belum terampil dan jarang memakai kamus. Masalah utama kedua adalah bahwa mereka hanya memiliki pengetahuan tentang unit-unit leksikogramatikal yang terbatas. Peranti penting yakni kata-kata gramatikal sering diabaikan sehingga sulit untuk memahami pola-pola urutan kata dalam suatu rangkaian kalimat.
\end{abstract}

Kata Kunci: kata-kata gramatikal, leksikogramatikal, pola urutan kata.

\section{Introduction}

The research for this paper was carried out in 2008-2009 at Tarbiyah's class where I had an opportunity to be able to teach English subject. According to my observation conducted to 125 Tarbiyah's college student, 76 percent of the students said that English was very important for their study and 66 percent of them said that vocabulary was their problem. That some students said that grammar was their main problem was because they hardly knew about English vocabulary or grammar. Nevertheless, they felt that they know vocabulary better than grammar because they could check the meaning words in the dictionary. Therefore, the in-depth interview data draw from 78 students revealed that $85 \%$ of the students' problem was vocabulary. They said that they had less problems with grammar because they had already learned grammatical items since they were in high school and grammatical item were also relatively finite number, while vocabulary was open ended. 
It is true that reading does not depend on vocabulary alone, but the nature of the reading threshold is largely lexical. There are at least four factors influencing reading: three are reading factors and one is a language factor. ${ }^{1}$ Vocabulary takes a very important part in the language factor. Second Language university student's lexical errors outnumbered grammatical errors by $2: 1$ or $4: 1 .^{2}$ Vocabulary difficulty has long seen used as the most significant predictor of overall readability. The reading factors include reading ability in first language, strategies in second language, and the ability to employ first language reading strategies in second language. Related to the reading skill ${ }^{3}$, Laufer claimed that before one reaches 95 percent lexical coverage he will not be able to transfer the reading skills from first language to second language.

\section{Information About The Word}

Knowing a word is to know all kinds of information about the word since a word has complex features. It is not only to recognize it when it is seen, or to match it with its native language counterpart. To know a second language word is to be able to use the word communicatively in the context of purposeful interaction because a word, for lexical and grammatical collocations, is also related to other words in a language.

Thus word knowledge includes phonological information such as sound patterns, pronunciation, and spelling; morphological information such as derivation, conjugations, and compounding; syntactic and textual information such as word classes and possible

\footnotetext{
${ }^{1}$ Laufer, B. Taking the Easy Essay Out: Non-Use and Misuse of Contextual Clues in EFL Reading Comprehension. (Clevedon, 2005: Multilingual Matters). p. 44

${ }^{2}$ Mesara, P. "The Study of Lexis in Interlanguage" In The Study of Lexical Interlanguage. (Edinburg, 1984: Edinburg University Press), p. 89

${ }^{3}$ Laufer op.cit., p. 67
} 
relations with other classes and sentences; pragmatics information such as ${ }^{4}$ social and stylistic adequacy of use; and, finally, semantic information about the meaning of word, with all its connotations, which refer to the concept and the conceptual network of the word. In fact, words are not single entities but labels of concept, which are embedded in larger domains of knowledge that constitutes knowledge of the world. A concept can be described as the total collection of meanings, associations, ideas, and images linked to a word.

In most English courses in Indonesia vocabulary is not explicitly taught systematically. Learners are expected to learn it on their own without much guidance. The fact of the matter is that mastery of vocabulary needs some training, tutored or untutored..$^{5}$ The vocabulary instruction had not been considered as the vital part of reading programs was much influenced by Goodman's notion of reading ${ }^{6}$, since reading, according to Goodman, is a guessing game. Reading models based in this notion was known as the to-down model. With the advent of interactive model posits it that rapid vocabulary recognition with lexicogrammatical knowledge plays a crucial role in good reading.

3. Understanding Texts and Lexicogrammatical Relations

\subsection{Understanding Texts}

It is generally assumed that, to a large extent, reading texts contribute a great deal of knowledge to vocabulary learning; in a similar fashion, little knowledge of vocabulary

\footnotetext{
${ }^{4}$ Seiler and Wannenmacher. "How can we Assess Meaning and Investigate Meaning Development: Theoretical and Methodological Considerations from an Epistemological Point of View." In T.B. Seller. Concept Development and the Development of Word Meaning. (Berlin, 1983: Springer). P. 109

${ }^{5}$ Brendan Heasly. Semantics. (Cambridge, 2001: Cambridge University Press) p. 65

${ }^{6}$ Goodman, George. Reading and Vocabulary (Cambridge, 1967: Cambridge University Press), 213
} 
will lead to a significant decrease of comprehension ${ }^{7}$. For communication, generally college students must understand approximately $60,000-100,000$ word. ${ }^{8}$ The need to acquire vocabulary becomes increasingly important when learners face real conversation and authentic texts. Higher-intermediate and advance student may have a greater problem with vocabulary. Even elementary or lower intermediate learners need lexical resources to cope with highly restricted range of speech events. Based on this crucial role of vocabulary, Second Language (henceforth, L2) learners have to get ready for the task of capturing and taming the mass vocabulary that surrounds them. This suggest that beginning language students have to store much vocabulary in their long term memory within a short amount of time.

\subsection{Lexicogrammatical Relations}

Lexicogrammatical relations in this present paper refers to words for understanding sentences. Lexis is chained in sentences. Thus at the sentential level knowing a word requires at least the morphological, syntactic and collocational aspects of the word. Lexis and grammar were separated in traditional grammar, but they are actually closely related and we call it lexico-grammatical relations. ${ }^{9}$ Thus, while reading learners should also use their lexical structuring skill in text, but the problem is that learner usually know partial knowledge of a word, and, thus, they process underdeveloped vocabularies. For instance, at the first entry to Tarbiyah college student as I observed in their diary study that as a beginner they were in high need of grammar reference because of complex morphological elements in the language.

\footnotetext{
${ }^{7}$ Ibid, p. 20

${ }^{8}$ Mackey, W.F. Language Teaching Analysis. (London, 1965: Longman) p. 123

${ }^{9}$ Sinclair, JMcH. "Sense and Structure in Lexis" In J.D. Bensen, M.J. Cummings, and W.S. Greave (eds). Linguistics a Systemic Perspective. (Amsterdam, 1988: Benjamin) p.43
} 
Grammar and vocabulary actually were separated field. Currently, however, vocabulary has been used as the organizing principle of language teaching courses. Words have also been used to present patterns; the pattern approach to vocabulary extends far beyond the grammatical approach to pattern. In fact, to use language is to select more than one word at a time. Words occurs together to make collocational patterns or set phrases. Words. Do not combine and recombine freely and randomly with others, for instance, running color, height of the summer, cute little star, are lexical collocation, while guilty of (-ing) and it v-link adj to -inf are grammatical collocations or lexicogrammatical units. Grammatical collocation consist of a noun, an adjective, or a verb, plus a preposition or a grammatical structure such as infinitive or a clause. Lexical collocations do not contain preposition, infinitive or a clause but consist of various combinations of nouns, adjectives, verbs and adverbs. ${ }^{10}$ Although those combinations are analyzable in term of syntactic rule, they are stored and produced as single chunks. Thus, the sharp distinction between vocabulary and grammar has been narrowed down to crystallized regularity, and eradicate the artificial division between vocabulary and grammar, which impoverishes the teaching of both. Grammatically at the present time refers to a prepositional phrase, but lexically it is a unit which is often synonymous with the word now. Based on psycholinguistics point of view is how speakers store and retrieve the language system, and how learners acquire the language. It is argued that lexical phrases play an important role in both processes. Fact from first language acquisition indicates that lexical phrases are learned together with their associated functions in context. For instance, children frequently use a phrase such as I-want-to-

\footnotetext{
${ }^{10} / \mathrm{bid}$, p. 29
} 
drink-milk, as though it were a single unsegmented unit. Gradually, in the process of acquiring other chunk with similar syntactic patterning I-want-my-doll, I want to eat, the child detaches the pattern from its connection in context, and analyses and generalizes it into regular syntactic rules. As syntactic rules emerge, this language chunk-analysed or not — continues to be available for ready access as either a partially or holistically preasssembled pattern.

The storage capacity of memory is vast, but that the speed for processing those memories is not. Many studies of language processing thus suggest that language is stored redundantly. Words, for example, are stored no only as individual morphemes, but also as parts of phrases, or as longer memorized chunks of speech, and that they are often retrieved from memory in these pre-assembled chunks. Therefore, to learn a language in it lexicogrammatical units has both the advantage of more efficient retrieval and permitting speakers or readers to direct their attention to the larger structure of the discourse rather than keeping it focusing narrowly on individual words as they are produced.

\section{Research Questions}

In this present paper the Tarbiyah college students' problem to understand the sentences in their major textbooks were explored for helping them to read more accurately. With this problem in mind, the three main research questions that guides this investigation were:

1) Considering their present vocabulary size, do students still need to enhance their vocabulary size? 
2) What vocabulary is unknown for students: low frequency or high frequency?

3) Can they read those sentences if they use their dictionary?

4) What are the students' problems in understanding the meaning of the sentences in their textbook?

\section{Methodology}

The data obtained in this present paper was taken from an action research conducted to Tarbiyah college students in their first semester at Manado State Islamic Study. The students took this course as required in the curriculum 90 minutes a week with 3 credits.

To answer the first question : Considering their present vocabulary size, do students still need to enhance their vocabulary size? A standardized vocabulary size test, students still need to enlarge their vocabulary size. The unfamiliar words students collected and at the end of the semester those collected words were categorized computed. In every meeting every student was required to individually collect twentyfive unfamiliar words from the textbooks assigned by their content lectures to read. They should look up the meanings in the dictionary and they should be able to say the meaning of words when the instructor quizzed them. They should also try to translate the sentences where they found the words. The students were required to report the twentyfive words they collected on a list. At the end the semesters to know which categories those words belonged to, they were compared to three base lists, the first 1000, 2000, and 3000 words. 
NUR HALIMAH - Vocabulary And Lexicogrammatical.......

\section{Finding}

\subsection{The Tarbiyah college students' Present Vocabulary Size}

At the first meeting vocabulary learning texts, a standardised vocabulary size test was administered and it was discovered that the Tarbiyah college students' average size was 932 word families, ranging between 213 and 2001 words, with standard deviation (SD) 125 shown in Table 1 below:

\begin{tabular}{|l|l|}
\hline No student & Vocabulary Size \\
\hline 1 & 234 \\
\hline 2 & 453 \\
\hline 3 & 482 \\
\hline 4 & 543 \\
\hline 5 & 456 \\
\hline 6 & 554 \\
\hline 7 & 654 \\
\hline 8 & 765 \\
\hline 9 & 876 \\
\hline 10 & 877 \\
\hline 11 & 987 \\
\hline 12 & 1077 \\
\hline Mean & 663 \\
\hline SD & 221 \\
\hline
\end{tabular}

A questionnaire was also distributed and it was found that there were only two students who said that they did not have any problem to read English textbooks, but eleven of them and the rest even admitted that they were discouraged to try.

\subsection{The Tarbiyah college students' Unfamiliar Vocabulary}

The words collected by the students over the course were analysed. Almost 2000 (to be exact, 1950) words were collected. It was discovered that the students were unfamiliar with: 675 word families of Baseword 1 (henceforth, BW) (the first 500 most 
frequent word), 235 words families of Baseword 2 (the second 500 most frequent words), Baseword 3 (the third 500 most frequent words), and 500 words not in the list (the words beyond the 3000 most frequent words) as shown in table 2 below:

\begin{tabular}{|l|l|l|l|}
\hline Category & Number & $\%$ & \multirow{2}{*}{ BW 1-3 \% } \\
\hline Baseword 1 & 350 & 17 & \multirow{2}{*}{87} \\
\hline Baseword 2 & 575 & 29 & \\
\hline Baseworth 3 & 786 & 40 & \\
\cline { 1 - 3 } Not in the list & 239 & 12 & 13 \\
\hline Total & 1950 & & \\
\hline
\end{tabular}

Table 2: the numbers of students' unfamiliar word families according to Baseword 1, Baseword 2, Baseword 3, and words not in the list. Code: BW 1-3= Baseword 1, 2, 3.

The words in Basewords 1, 2, and 3 were frequently encountered by Tarbiyah college students, and, consequently, the same words were unkown and collected by a great number of students, but the low frequency words were rarely encountered by the college students, and each word was collected by one to three college students only. Some of those collected words are shown in Table 3 and 4. Among the ten words displayed in Table 3 the two unfamiliar word that college students met most frequently were achievement and appropriateness. Table 4, however, displays the lower frequency words college students collected, and because they were rare words, each word was encountered by one student only.

The students were not only unfamiliar with rare and technical words, but also high frequency words such as amount, animal, bake, baffle, henceforth, though, dabble, improvident, proponent and sorghum. They were also unfamiliar with cognate, as Indonesia spelling system is not the same as the English spelling system. For instance, soulful, thrill, unhook, unerring, deficit, dam, dammit. It can be inferred, then, that the college students might not be used to English speaking system, hardly read English. 
NUR HALIMAH - Vocabulary And Lexicogrammatical.......

Table 3: Number of Students who did not know the 83 of the words belonging to Baseword 1

\begin{tabular}{|l|l|l|}
\hline No & Words & Number of students \\
\hline 1 & Alignment & 4 \\
\hline 2 & Altruism & 8 \\
\hline 3 & Breach & 8 \\
\hline 4 & Brunt & 9 \\
\hline 5 & Cerebral & 5 \\
\hline 6 & Chancy & 4 \\
\hline 7 & Cheat & 11 \\
\hline 8 & Decline & 1 \\
\hline 9 & Decrease & 6 \\
\hline 10 & Deviate & 9 \\
\hline 11 & Ensemble & 10 \\
\hline 12 & Entice & 5 \\
\hline 13 & Flowery & 2 \\
\hline
\end{tabular}

Table 4: Number of Students who did not know the 13 of the words belonging to Baseword 1-3

\begin{tabular}{|l|l|l|}
\hline No & Words & Number of students \\
\hline 1 & Arrive & 2 \\
\hline 2 & Assert & 3 \\
\hline 3 & Accompany & 2 \\
\hline 4 & Blank & 2 \\
\hline 5 & Bowl & 2 \\
\hline 6 & Board & 2 \\
\hline 7 & Carefree & 3 \\
\hline 8 & Certify & 3 \\
\hline 9 & Damage & 3 \\
\hline 10 & Definable & 3 \\
\hline 11 & Deviate & 3 \\
\hline 12 & Differ & 2 \\
\hline 13 & Extend & 2 \\
\hline
\end{tabular}

When the Tarbiyah college students were reading practice, and during my observation in the class they were too many words in a sentence that the students did not know. For instance, they did not know the words human, being, opposable, thumb, pick up, distinctive, shape, a boot, schoolchildres, easily (1-2). Sentence (1-2) consist of thirty-two words of nineten types and 
there were four words a student did not know, and all those four words are high frequency words. S-1 (Student-1), for example, did not know 1 in 5 words in this following sentence:

(1) Human beings have opposable thumbs because they can easily pick things up and hold them.

(2) Italy has distinctive shape of a boot because schoolchildren can usually identity it easily on a map.

(3) Before beginning any detailed discussions, we need a definition of contact language.

There are twelve running words in (3) and they are made up of twelve types, but there were seven words which S-3 (Student 2) did know, this means that S3 did not know one in four words:

(1) I started a letter to my parents yesterday. I though about finishing it last night before I went to bed, but I didn't. I already haven't finished it.

Almost every college student had the same problems, which were serious. One was that they did not know one among four to five words, it was also discovered that the students' lexical problems were not only restricted to low frequency words, but also high frequency ones. Table 5 shows the words collected by two college students, S-4 and S-5 - and other student, too-were still unfamiliar with grammatical words like such and which. They were also unfamiliar with names of colors, which learners usually learn very early in their English training. They could not recognize cognates like marine, concentrate, solution, indicate, and classifying.

At the second meeting it was also discovered that the students did not use technical dictionaries, such as the dictionaries the education, chemistry, biology, and mathematics, because they still could not use a monolingual dictionary. Students came to class with unknown words which they could not look them up in their bilingual general dictionaries, like the words trochopos, code switching, and bilingual. They said that what they did not know was only one word, but when they wanted check the meaning in a technical dictionary they had many more word they did not know, because the technical vocabulary definitions were very long and contained more unfamiliar words. 
NUR HALIMAH - Vocabulary And Lexicogrammatical.......

Table 5: Two list of word collected by 3 college student in two weeks

\begin{tabular}{|l|l|l|l|}
\hline No & Student 1's collected words & Student 2's collected words & Student 3's collected words \\
\hline 1 & Barly & Art history & Naturally \\
\hline 2 & Concern & Be dependend on & Container \\
\hline 3 & Maize & Car of corn & Ancient \\
\hline 4 & Tool & Ham sandwich & Plentiful \\
\hline 5 & Weapon & Have knowledge of & Control \\
\hline 6 & Climatic & Part of speech & Store \\
\hline 7 & Tame & Bank robbery & Tremendous \\
\hline 8 & Store & Doughnut & Vast \\
\hline
\end{tabular}

At the third meeting the students' problem in using dictionaries were explored. The researcher brought in a desk dictionary and technical dictionaries to class. She fimiliarised the students with the use of dictionaries and helped them understand the dictionary definitions of those technical words. It also became more obvious that the students still had a problem to decide which dictionary definition under one entry was the most appropriate for unknown word in the context. With the lecturer's explanation, they found that usually they were not careful and patient enough to choose the right meaning especially when they were already familiar with one particular definition. For example, if they knew that the word since means sejak, they did not want to check other possibilities; for example, whether it can also that the word cause means 'karena', and they did not have the slightest idea that a word may have several definitions.

Based on this fact, it seemed that the students were still not ready to use large monolingual dictionaries. They did not try and preferred to wait for help. A student came up and asked the researcher what the meaning of word constrains was because he could not find it in his dictionary. Actually the dictionaries were already on the table and the students were free and encourages to use them, but this student did not want to look it up himself. He quietly sat down and the researcher look it up for him. First, the researcher used the Webster desk dictionary but the word wasn't listed in it; instead it was listed in the dictionary of education. To understand the dictionary definition, however, another unknown word, no constrains, appeared. This time she could not find the meaning of the word in the dictionary of education but in Webster desk 
dictionary. During the searching process the student did not want work together with the researcher to locate the word in the dictionary, but after the researcher found the meaning of the word, the student stood up and copied the intend definitions. The student said that it was to complicated and he was not able to do it. Actually the thirteen other student present in class were also reluctant to use the dictionary. They said that it was not easy to use a monolingual dictionary.

7. Discussion

\subsection{College Student's Vocabulary Size}

With a vocabulary size 1232 words reading could be depressing task. Even one student has less than 500 words, which indicates that he hardly knew English. Only one had vocabulary of 2.000 most frequent words can already approximately cover $87 \%$ of the tokens in an average text, there area still 102.000 headwords students need to know and insufficient knowledge about them can pose a formideable problem. Furthermore, rare type of words in a text are those which carry the highest information load, and therefore, cause the most hindrance in the reading process when unkown. Students themselves realized about their problem and they reported that reading English textbooks as not a soft task for them. Guessing in context is not without its problem and it may also result in erroneous guesses. With the current status of vocabulary size students needed to at least double their vocabulary size because to read an ordinary academic text a reader needs a vocabulary of a least 4,000 to 5,000 word families. Note that 5,000 words must include most of the 2,000 words families of the high frequency words and the 800 university words. Only this way, college students had the access to read their textbook effortslessly and immediately without having to devote too much to lexical guessing. Therefore, during the observation it was discovered that in a sentence of twenty running words with twenty types, there were five words student did know or they did not know one among three words. Because of their limited vocabulary and lexicogrammatical skill in one session of 60 minute students normally could only read or translate two to five sentences (about 60 words) from their textbook with a lot of difficulties and inaccurate result.

\section{Conclusion}


A class of Tarbiyah students' at STAIN Manado was found to have an average vocabulary size of 1231 words families. This is one reason why reading become very tedious for the because they did know one among four words, and they were also still unskilled in using their dictionaries. Sometimes they were also reluctant to use their dictionaries; they ignored some unkown words, and sometimes employed the word guessing strategy, the result of which was misleading for getting the meaning of the sentences. In fact, they had been discouraged to use their word guessing strategies. At their level of proficiency, guessing will not be really usefull, except for cognate, and for derived words after some training with English root and affixes. Only advance student can derive more advantage from guessing. With their current vocabulary size autonomous learning was also still difficult, and instruction was still needed. The kind of words students did know still included the basic high made $25 \%$ of their unknown words. They also underestimated little and grammatical words. If we believe in the lexicogrammatical approach of second language learning, grammatical words are quite important to introduce lexicogrammatical pattern. The second reason was that the students did not really know about lexicogrammatical patterns. Their vocabulary knowledge was still underdeveloped, or they did not know all kinds of information needed to understand a word, including how a word combines with other words to make lexicogrammatical pattern. Consequently, after knowing every meaning of the words in a sentence the students still get the wrong meanings of the sentences they read. In fact, they had many unfamiliar words in a sentence and relied on their dictionaries for obtaining individual meanings of the lexical words were not processed in chunks. One solution which can be offered to solve this problem, which still needs further investigation, is to help the Tarbiyah college students collect learn their lexicogramatical patterns. Thus, they can do their own concordancing, in addition to the learning of the meaning lexical words only like in this current study. 


\section{REFERENCES}

Bolinger, D. 1975. Aspects of Language. New York: Harcourt Brace Jovanovich.

Carter, M and Mc Carthy. 1988. Vocabulary and Language Teaching. London: Longman

Honeyfield, J. 1977. "Words Frequency and the Importance of Context in Vocabulary Learning". RELC Journal, 8(2).

Kweldju, S. 1999 “ English Department Student : Collocation Ability” TEFLIN Journal, 10(1)

Mackey, W.F. 1965. Language Teaching Analysis. London: Longman

Nation, I.S.P. 1990 Teaching and Learning Vocabulary. New York: Newburry House

Peters, A. 1983. The Unit of Language Acquisition. Cambridge: Cambridge University Press.

Sinclair, J.McH. 1988. "Sense and Structure in Lexis" In J.D. Bensen, M.J. Cummings, and W.S. Greaves (eds) Linguistics in a Systemic Prespective. Amsterdam: John Benjamin

Vermeer, A. 1994. Exlporing the Second Language Learnier Lexicon”. In L Verhoeven and John HAL de Jong. The Costruct of Language Proficiency Applications of Psychologidal Models to Language Assesment. Amsterdam: John Benjamin. 